\title{
Assessing the Impacts of Organizational Culture and Sales Promotion on Consumer Buying Behavior: A Case of Telecom Sector
}

\author{
Fazal ur Rehman ${ }^{1 *}$, Rosman Md Yusoff ${ }^{2}$, Fadillah Ismail ${ }^{3}$ \\ ${ }^{1}$ Fakulti Pengurusan Teknologi dan Perniagaan, \\ Universiti Tun Hussein Onn Malaysia, Parit Raja, Johor, MALAYSIA
}

${ }^{2}$ TRANSFORM,

Universiti Tun Hussein Onn Malaysia, Parit Raja, Johor, MALAYSIA

*Corresponding Author

DOI: https://doi.org/10.30880/jstard.2019.01.02.005

Received 29 September 2019; Accepted 22 November 2019; Available online 17 December 2019

\begin{abstract}
This study aims to examine the impacts of organizational culture and sales promotion on the buying behavior of Pakistani consumer's. This study has collected data through self-administered questionnaires from the consumers of Telenor, a telecommunication company in Pakistan. The collected data were analyzed through linear regressions to determine results. This study is based on the marketing event of Telenor. Results have indicated that organizational culture and sale promotions have positive significant relationship with the buying behavior of Pakistani consumers in telecom sector. It has noted that organizational culture is positively correlated to sales promotion. The study has suggested that marketing professional can apply the technique of organizational culture in sales promotion to affect the buying behavior of Pakistani consumers.
\end{abstract}

Keywords: Organizational culture, sales promotion, buying behavior

\section{Introduction}

Culture is the stimulating indicator of business custom and its uniqueness can impact the buying behavior of consumers in optimistic manner. Like, Mooji and Hofstede (2002) have projected the affect of culture attraction on the buying psyche and purchase decision of consumers. Kumar (2007) has assessed this conception and assumed that a culture has profound implications on the psyche of consumers. In the same manner, a study of Kacen and Lee (2002) have examined the role of culture in affecting buying behavior of consumers and explored the importance of cultural context and its affect on consumer's behavior in globalized market. It was confirmed in the study that cultural factors have significant impacts on the buying psyche and behavior of targeted consumers. At the same time, Loudon and Bitta (2002) have presumed that consumer behavior is a value building activity and has considerable role in influencing their buying decision and can affect the organizational objectives in positive or negative directions. While, sale promotion is one of the interesting technique from last few years to enhance market shares and instant sale to achieve the objectives of profit gaining. For example, Chaharsoughi and Yasory (2012) have observed an increase in the sales promotional tactics and wide interest of businesses in Indian market. The estimated cost of sales promotional activities was recorded with 600 percent increase in last three to five years at India. Hence, organizational culture and sales promotion are two vital factors that can impact the buying psyche and purchase decision of consumers. Due to the reason, this study has examined whether a specific organizational culture and sales promotion have any relationship with the buying behavior of Pakistani consumers in telecom sector? For getting this aim, a study was conducted in telecom sector of Pakistan to examine the impacts of organizational culture and sales promotion on the buying behavior of consumers. 


\section{Literature Review}

\subsection{Organizational Culture}

Culture may be an imperative part of a society to sustain its uniqueness and set apart it from others. It is assumed that a culture is the way of life of a group of people where norms and beliefs are shared among and may influence their behavior. Like, Triandis (1989) has noted that societal norms and beliefs have affects on the temper and behavior of consumers. As values, myths, customs, and language are the significant elements of every culture and transmitted from parents to their children's (Lamb et al., 2011). (Goodenough, 1971; Kroeber \& Kluckholn, 1952; Schwartz \& Bilsky, $1987 \&$ 1990) have proposed the definition of a culture as "Culture is the set of norms and beliefs that are shared amongst a group of people and that provide the guiding principles of one's life". Culture is comprehensive in nature, logically fitted, acceptable to other, it is learned instead of born with and displayed in satisfactory mood (Permer, 2013).

Culture might represent the norms of a business and show traditions of behaving. This custom may affect the buying behavior of consumers. It is assumed that an accepted culture can affect buying decision of consumers. Like, Mooij and Hofstede, (2002) have noted that the standardization or localization of a culture can also affect buying decisions of consumers. Nakata and Sivakumar (2001) have conducted a study and presumed that a culture has impacts on several aspects of marketing like customers response to sales promotion. Therefore, a need is observed to understand culture involvement in sales promotion as "there is a need for research directed at understanding culturally-driven responses of consumers to promotional activities" (Bridges et al., 1996). However, the study has acknowledged that the applications of culture can affect the buying behavior of consumers.

\subsection{Sales Promotion}

The efforts and campaigns of sales promotion are used to enhance and boost up the instance sale. Such as, Peattie (1998) has anticipated sales promotion as a seasonal or special discount offer to consumers to achieve the instant objectives of profit gain. Exactly, it is the application of marketing strategies to add value in prices for consumers to achieve organizational objectives (Bunn \& Banks, 2004). Likewise, Boddewyn and Leardi (1989) have defined as "sales promotion is the marketing devices and techniques which are used to make goods and services more attractive by providing some additional benefit, whether in cash or in kind, or the expectation of such a benefit". While, Branch (1990) has supposed sales promotion as a marketing technique with a wide range of benefits to consumers such as coupon, bargaining, providing free sample, accessible points of display and purchase promotion rather than advertisement through paid media. Similarly, some researchers have mentioned sales promotion as a periodic or seasonal offer to improve the short term sales of a business for profit gain and reduce stock (Kotler et al., 2006), and linked with a specific period or an event (Peattie \& Peattie, 1995; Lehman \& Winer, 2002; Walsh, 2000).

To get value in term of saving is the prime benefit of sales promotion (Blattberg \& Neslin, 1993), as consumers most often prefer to buy good quality products during sales promotional activities to save some portion of money. It was observed that sales promotion can save the money of consumers, can motivate toward bigger sale, can easily convince the targeted consumers, reduce stock, and can provide the opportunity of social interactions and entertainment. However, literature has divided sales promotion in Utilitarian (tangible) and Hedonic (intangible) benefits to maximize the operational efficiency and excellence for consumers buying utility. In the same way, literature has highlighted several types of sales promotion to affect the buying psyche of consumers (Dickson \& Sawyer, 1990; Dhar \& Hoch, 1996; Hoch et al., 1994), such as, monetary (short term incentives) and non-monetary (long term incentives) to convince existing and new customers toward a business (Campbell \& Diamond, 1990; Tellis, 1998). It can increase the volume of sale (Hanssens et al., 2001), and influence the buying behavior of consumers (Ailawali \& Neslin, 1998).

\subsection{Buying Behavior}

Buying behavior is the process to observe need, searching for solution, gather information, buying a product or service, using to get experience, disposing, and generate opinions (Engel, et al., 1986). Therefore, some studies have mention critical features of consumers behavior like mental, physical and emotional activities that often keep them involved in selecting, purchasing and usage of products or services to solve their problems (Wilkie, 1994; Pariest, Carter \& Statt, 2013), and can influence their buying decisions (Schiffman \& Kanuk, 2004). Further, (Furaiji et al., 2012) have suggested that consumer buying behavior include a sequence of steps, initially consumers note some issues, searching for solutions, buying some things to get solutions, assess existing information's, setting plans and streamline resources to complete it in efficient way. However, Staykoya et al., (2008), have presumed a new dimension and suggested that consumer's often purchase due to personal perceived values but not due to functions. 


\subsection{Organizational Culture and Consumer Buying Behavior}

In 2003, Kotler has highlighted several factors like social and economic values that influence buying process and behavior of consumers. It has noted that culture is one of the fundamental factors to influence the buying behavior of consumer's. Likewise, Luna and Gupta (2001) have determined the influence of culture on the buying behavior of consumer's and found that culture has significant effects on the buying behavior of consumers. Ogden and Schau (2004) have noted the similar affects of culture on the buying behavior of consumers. Usunier (2000) has found a list of some features which are affected by culture, like, buying behavior, perception, motivation, learning, age, gender, social class and some other. There is also evidence from Samli (1995), where a set of variable was suggested like; language, class structure, work ethics, need for privacy, learning, religion, family size, territoriality, tradition orientation and some other which affects the buying decision of consumers.

Manrai and Manrai (1996) have proposed a model to assess the influence of culture on consumer buying behavior. It was noted that a culture is complex and is difficult to identifying its effect. However, the study preferred to assess the different parts of culture and grouped it in categories like social, personal and psychological factors. These parts were further divided for assessment, like, product acquisition and its usage, acceptance and dispersion of innovation, responding to sales promotion, response to channel of distribution and various mod for products payment. Later on, Luna and Gupta (2001) have noted an influence of culture on the buying behavior of consumers in direct and indirect way. The study has noted the effects of culture on the behavior of consumers in the aspects of values, heroes, ritual and symbols. Therefore, this study is interested to examine the impacts of Telenor culture on the buying behavior of Pakistani consumers.

\subsection{Sales Promotion and Consumer Buying Behaviour}

Schultz (1998) has examined the association between sale promotion and the buying behavior of consumers and found a direct relationship among the two constructs. While Dwyer and Tanner (2006) have described consumers a key source to achieve economic objectives. It was observed that sales promotion is the helpful technique to achieve the profit oriented objectives (Gardner \& Treved, 1998). Ngolanya et al., (2006) have praised the factors of sales promotion (such as coupons, discounts, rebates and sample) to enhance the buying decision of consumers. As consumers often prefer feature added buying (Kotler et al., 2003; Stanton et al., 1994). The factors of sales promotion can catch the consumers' attention in significant way (Ngolanya, et al, 2006). However, literature has highlighted organizational culture and sales promotion in different context around the world, while this study has noted a gap of knowledge to determine the impacts of organizational culture and sales promotion on the buying behavior of Pakistani consumers during the promotional event of Telenor. Therefore, this study has developed the following conceptual framework to determine the association among defined constructs.

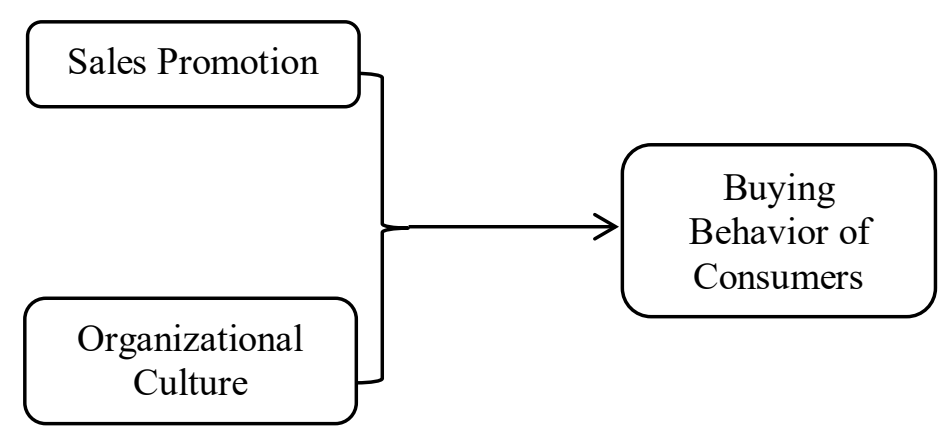

Fig. 1 - Conceptual Research Model

$\mathbf{H}_{1}$ : Organizational culture has positive impacts on the buying behavior of Pakistani consumers.

$\mathbf{H}_{2}$ : Sales promotion has positive impacts on the buying behavior of Pakistani consumers. 


\section{Metodologi}

The study has applied positivist approach to collect data through self-administered questionnaire from 336 respondents. The study selected sample size of 382 on the basis of Morgan Table. The respondents were the students in Rawalpindi and Islamabad region of Pakistan. They were the users of Telenor and have observed the promotional events of it. The set of questionnaire was distributed to collect the demographic and the vital information's about the defined variables. The questionnaires was adopted and adapted from (Chaharsoughi \& Yasory, 2012; Cardoso \& Figueiredo, 2014; Rehman et al., 2014; Park et al., 2013 and Osman et al., 2011). To ensure the reliability of instrument, a pilot study was completed by collecting data from 50 Telenor users. The results of pilot study are presented in the following table:

Table 1 - Values of Cronbach Alpha of Pilot Study

\begin{tabular}{ccc}
\hline Variables & No of items & Cronbach Alpha \\
\hline SP & 7 & 0.721 \\
OC & 6 & 0.825 \\
BB & 6 & 0.843 \\
\hline
\end{tabular}

\section{Results}

This study has used correlation statistics with the aim to understand the correlation among defined variables. The following table is presenting the results of correlation.

Table 2 - Results of Correlations

\begin{tabular}{lccc}
\hline \multicolumn{1}{c}{ Variables } & $\begin{array}{c}\text { Sales } \\
\text { Promotion }\end{array}$ & $\begin{array}{c}\text { Organizational } \\
\text { Culture }\end{array}$ & $\begin{array}{c}\text { Buying } \\
\text { Behavior }\end{array}$ \\
\hline Sales Promotion & 1 & & \\
Organizational Culture & $0.271^{* *}$ & 1 & 1 \\
Buying Behavior & $0.652^{* *}$ & $0.436^{* *}$ & 1 \\
\hline
\end{tabular}

** Correlation is significant at the 0.01 level (2- tailed)

The results of correlation are presented in the above table. Results have indicated that sale promotion is positively correlated to organizational culture $(r=0.271)$ as well as buying behavior $(r=0.652)$. Similarly, organizational culture is also positively correlated to the buying behavior $(r=0.347)$ of consumers.

Table 3 - Regression Analysis

\begin{tabular}{lccc}
\hline & Beta Value & $\begin{array}{c}\text { Standard } \\
\text { Error }\end{array}$ & P Value \\
\hline Sales Promotion & $.734^{* *}$ & .058 & .002 \\
Organizational Culture & $.261^{* *}$ & .050 & .000 \\
F value & & $12.38^{* *}$ & \\
$\mathrm{R}^{2}$ & .132 & \\
Adjusted $\mathrm{R}$ & .151 & \\
$* * \mathrm{P}<0.01, * \mathrm{P}<0.05$ & & \\
\hline
\end{tabular}


Table 3 shows the result of regression. Sales promotion has strong positive significant relationship with the buying behavior of Pakistani consumers. It can be inferred from the results that sales promotional activities of Telenor has significant impacts on the buying behavior of Pakistani consumers as its marketing techniques in sales promotion may effectively create consumers attentions. It can also be inferred that Telenor sales promotion may provoke its consumers' to purchase the products. It's also possible that Telenor may offer a variety of incentives to customers in sales promotional activities. Results have shown that organizational culture has a weak positive significant relationship with the buying behavior of Pakistani consumers in telecom sector. It can be contingent on the basis of results that Telenor culture has positive impacts on the buying behavior of Pakistani consumers due to its customs and uniqueness in culture. Similarly, it may also possible that the moral behavior in Telenor sales promotion may have positive influence on consumers buying behavior as it may pertinent to the cultural context of Pakistan.

\section{Discussion}

This study has assessed the impacts of organizational culture and sales promotion on the Pakistani consumers buying behavior in telecom sector. Results indicated that organizational culture and sales promotion have positive impacts on the buying behavior of Pakistani consumers. Results also indicated that organizational culture and sales promotion are positively correlated with the buying behavior of Pakistani consumers. However, in regards of marketing implications, this study has contributed to existing knowledge that affective organizational culture and sales promotion can impact the buying behavior in affirmative way. While in term of managerial potential, this study was interested to determine whether organizational culture and sales promotion have any impacts on the buying behavior of Pakistani consumers during the promotional celebrity of Telenor. However, the results have confirmed that organizational culture and sales promotion have significant impacts on the buying behavior of Pakistani consumers. Further, it was also observed that sales promotion has stronger impacts on the buying behavior as compared to organizational culture. The study is in line to Halliru (2013) in term of determining the influence of culture on buying behavior. It has found that the collectivist nature of consumers can affect buying behavior and male consumers have higher involvement as compared to female. The study has noted that regional advertisement and religion are more affective to influence buying behavior. In the same way, this study is parallel to Lawan and Zanna (2013) in term of determining the influence of socio-cultural factors on consumers buying behavior in Nigerian context. The study has noted that culture as in independent prospective or in conjunction with other factors (like personal and economic) have significant affects on the buying behavior of Nigerian consumers in cloth markets.

\section{Conclusion}

This study has investigated the impacts of organizational culture and sales promotion on the buying behavior of Pakistani consumers. The study has used quantitative technique to collect data through questionnaires based survey form universities students in twin cities (Islamabad and Rawalpindi) at Pakistan. It has used regression analysis to find results. Results have indicated that organizational culture and sales promotions have positive significant relationship with the consumers buying behavior. Therefore, the results of regression accepted the hypothesis of the study. Moreover, organizational culture and sale promotion are positively correlated with the consumers buying behavior. However, while interpreting the results, it is important to know that this study was limited to a small region and collected data from the universities students at Pakistan. So, the practitioners and readers should know in generalizing the results. This study recommends the assessment of moderators and mediators variable to further explore the relevant knowledge area in other sectors.

\section{Acknowledgement}

The authors sincerely acknowledge Universiti Tun Hussein Onn Malaysia for their support.

\section{References}

Ate. H. (2012). Ethical Perceptions of Public-Sector Employees and Citizens and their Impact upon Attitudes against Unethical Behavior. Turkish Studies. 13(1): 27-44.

Bandura, A. (1998). Health promotion from the perspective of social cognitive theory. Psychology and Health, 13: 623649 .

Bandura, A. (2008) An agentic perspective on positive psychology. In S. J. Lopez (Ed.), Positive psychology: Exploring the best in people (pp. 167-196). Westport, CT: Greenwood Publishing.

Bandura, A., and Locke, E. A. (2003). Negative self-efficacy and goal effects revisited. Journal of Applied Psychology, 88(1): 87-99. 
Block, J. and Kremen, A.M. (1996). IQ and ego-resiliency: Conceptual and empirical Connections and separateness. Journal of Personality and Social Psychology, 70(2): 349-361.

Carifio.J., and Rhodes. L. (2002) Construct validities and the empirical relationships between optimism, hope, self efficacy, and locus of control Work: A Journal o Prevention, Assessment and Rehabilitation, 19(2): 125-136.

Cardoso, A., and Figueiredo, J (2014) Attitudes of Children Related to Brands' Promotions, International Journal of Humanities and Social Science, 4(1): 113-122.

Coutu, D.L. (2002) How resilience works. Harvard Business Review. 80(3): 46-55.

Fredrickson, B.L., and Joiner, T. (2002) Positive emotions trigger upward Spirals toward emotional wellbeing. Psychological Science.13: 172-175.

Fu, W. (2013) The Impact of Emotional Intelligence, Organizational Commitment, and Job Satisfaction on Ethical Behavior of Chinese Employees. J Bus Ethics. Springer Science, Business Media Dordrecht.

Goldsmith A H.,Veum J R. and Darity W.(1997). The Impact of Psychological and Human Capital on Wages. Economic Inquiry. 35: 813-821.

Golparvar. M. and Azarmonabadi. A. R. (2014). Explaining Psychological Capital Components Through Organization's Ethical Climate Components. International Journal of Business, Economics and Management, 1(8): $216-228$

Halliru, M. (2013). Culture and Values in Consumer Behaviour: The Nigerian Experience. International Journal of Arts and Commerce. 2(10): 103-113.

Hui.Q., Cao. X., Lou. L. and He. H. (2014). Empirical Research on the Influence of Organizational Support on Psychological Capital. American Journal of Industrial and Business Management. 4: 182-189.

Lawan.A., and Zanna. R. (2013). Evaluation of Socio-Cultural Factors Influencing Consumer Buying Behavior of Clothes in Borno State, Nigeria. International Journal of Basic and Applied Science. 1 (3): 519-529.

Luthans F., and Youssef, C.M. (2004). Human, social, and now positive psychological capital management: Investing in people for competitive advantage. Organizational Dynamics. 33(2): 143-160.

Luthans, F., Norman, S. M., Avolio, B. J., and Avey, J. B. (2008). The mediating role of psychological capital in the supportive organizational climate-employee performance relationship. Journal of Organizational Behavior. 29(2): 219238.

Luthans, F. and Bruce J. A. (2007). Positive Psychological Capital: Measurement and Relationship with Performance and Satisfaction.Personnel Psychology. (60): 541-572.

Luthans, F. and Jensen, S. M. (2002). Hope: A new positive strength for human resource development. Human Resource Development Review, 1: 304-22.

Luthans, F. (2002a). The need for and meaning of positive organizational behaviour. Journal of Organizational Behaviur, 23(6): 695-706.

Luthans, F., Avey, J. B., Avolio, B. J., Norman, S. M., and Combs, G. M. (2006.) Psychological capital development: toward a micro intervention. Journal of Organizational Behavior. 27(3): 387-393.

Luthans, F., Avolio, B. J., Avey, J. B., and Norman, S. M. (2007) Positive psychological capital: Measurement and relationship with performance and satisfaction. Personnel Psychology. 60(3): 541-572.

Lehoczky, M.H (2013). The Socio-Demographic Correlations of Psychological Capital. European Scientific Journal October 2013 edition. 9(29): 26-42.

Luthans, F., and Youssef, C. M. (2007). Emerging positive organizational behavior. Journal of Management, 33(3): 321-349. 
Magaletta, P. R., and Oliver, J. (1999). The hope construct, will, and ways: Their relations with Self-efficacy, optimism, and general well-being. Journal of Clinical Psychology, 55(5): 539-551.

Masten, A.S. (2001). Ordinary Magic: Resilience processes in development. American Psychologist, 56(3): 227-239.

Marczyk, G.R. (2005). Essentials of Research Design and Methodology, Hoboken, NJ: John Wiley \& Sons.

Peterson, C. (2000). The future of optimism.American Psychologist. 55(1), pp. 44-55.

Peterson, S. J. and Luthans, F. (2003) The positive impact and development of hopeful leaders'. Leadership and Organizational Development Journal, 24: 26-31.

Pelletier. K.L, and Bligh. M.C. (2006) Rebounding from Corruption: Perceptions of Ethics Program Effectiveness in a Public Sector Organization. Journal of Business Ethics. pp. 10551-566.

Park, J.W., Choi, Y. and Moon, W (2013). Investigating the effects of sales promotions on customer behavioral intentions at duty-free shops: An Incheon International Airport case study, Journal of Airline and Airport Management, $3(1): 18-30$.

Qadeer. F, and Jaffery. H. (2014). Mediation of Psychological Capital between Organizational Climate and Organizational Citizenship Behavior. Pakistan Journal of Commerce and Social Sciences. 8 (2): 453- 470.

Osman, F., Fah, B.C.Y., and Foon, Y.S (2011). Simulation of Sales Promotions towards Buying Behavior among University Students, International Journal of Marketing Studies, 3(3): 78-88.

Richardson, G.E. (2002). The meta-theory of resilience and resiliency. Journal of Clinical Psychology, 58(3): 307-321.

Seligman, M.E.P. (1998) Learned Optimism. New York: Pocket Books.

Schneider, S.I. (2001) In search of realistic optimism. American Psychologist, 56(3): 250-263.

Shahnawaz. M. G, and Jafri. H. (2009) Psychological Capital as Predictors of Organizational Commitment and Organizational Citizenship Behaviour. Journal of the Indian Academy of Applied Psychology. 35, Special Issue: 78-84.

Snyder, C. R. and Lopez, S. (Eds.) Handbook of Positive Psychology. Oxford, UK: Oxford University Press, pp. 25776.

Snyder, C.R. (2002). Hope theory: Rainbows in the mind. Psychological Enquiry,13(4): 249-276.

Tiger, L. (1971). Optimism: The Biology of hope. New York: Simon \& Schuster. Tugade, M. M., and Frederickson, B. L. (2004). Resilient individuals use positive emotions to bounce back from negative emotional experiences. Journal of Personality and Social Psychology, 86(2): 320-333.

Walumbwa F. O. Luthans F., Avey J. B., and Oke A., (2011). Authentically leading groups: The mediating role of collective psychological capital and trust Journal of Organizational Behavior, 32, 4-24. 